\title{
Facilitatory Coupling between a Glutamate Metabotropic Receptor and Dihydropyridine-Sensitive Calcium Channels in Cultured Cerebellar Granule Cells
}

\author{
P. Chavis, ${ }^{1, a}$ J. M. Nooney, ${ }^{2, b}$ J. Bockaert, ${ }^{1}$ L. Fagni, ${ }^{1}$ A. Feltz, ${ }^{2}$ and J. L. Bossu ${ }^{2}$ \\ 'C.C.I.P.E., CNRS/INSERM, 34094 Montpellier, France, and 'Laboratoire de Neurobiologie Cellulaire, Centre de \\ Neurochimie, CNRS, 67084 Strasbourg, France
}

\begin{abstract}
The effect of metabotropic glutamate receptor activation on Ca dihydropyridine (DHP)-sensitive channels recorded in the presence of $1 \mu \mathrm{M}$ Bay K 8644 was examined on cultured cerebellar granule cells using the patch-clamp technique in the cell-attached configuration. Bath-applied agonist (transACPD, $1 S, 3 R$-, and $1 R, 3 S-A C P D$ isomers, and glutamate or quisqualate in the presence of CPP and (NQX) evoked an increase in $\mathrm{Ca}$ channel activity with a variable latency of $\mathbf{8 . 9}$ $\pm 8.6 \mathrm{sec}$ in $40 \%$ of the recorded cells. Neither L-CCG1, L-AP3, L-AP4, nor AMPA or NMDA activated Ca channels. Two dihydropyridine-sensitive channels present in this cell type were activated by trans-ACPD: the classical 24 pS L-type channel and a smaller-conductance $7 \mathrm{pS}$ channel. The effect was shown to be mediated by neither intracellular $\mathrm{Ca}^{2+}$ nor a pertussis toxin (PTX)-sensitive $G$ protein. Interestingly treatment with BAPTA-AM increased the number of responding patches and the activity was more sustained throughout the drug application. After overnight PTX treatment, activation of the $\mathrm{Ca}$ channels persisted even after washout of the agonist. These results indicate that mGluR1/mGluR5 probably mediate the facilitation of dihydropyridine-sensitive Ca channels.
\end{abstract}

[Key words: $\mathrm{Ca}^{2+}$ current, glutamate metabotropic receptor, Ca channel facilitation, cerebellum, $G$ protein, patch clamp]

Glutamate is a major neurotransmitter in the mammalian CNS. It activates two families of receptors, the ionotropic (AMPA, kainate, and NMDA) and the metabotropic glutamate receptors (mGluRs). Among the metabotropic receptor family, six receptor subtypes have been cloned (Houamed et al., 1991; Masu et al., 1991; Tanabe et al., 1992) and their pharmacology and coupling mechanisms characterized (Schoepp et al., 1990; Schoepp and Conn, 1993). The mGluR 1 and mGluR5 subtypes are positively coupled to phospholipase $\mathrm{C}$ and lead to inositol

\footnotetext{
Received Dec. 7, 1993; revised June 7, 1994; accepted June 16, 1994.

We thank Baycr France/Troponwerke (Germany), DRET (Direction des Recherches, Etudes et Techniques, 91/161), Rhône-Poulenc (J.B.), Human Frontier Science Program (J.B.), and E. Lilly (A.F.). J.M.N. held fellowships from Eli Lilly and Fondation de la Recherche Médicale.

Correspondence should be addressed to Dr. A. Feltz, Laboratoire de Neurobiologie Cellulaire, Centre de Neurochimie, 5 rue Blaise Pascal, 67084 Strasbourg, France.

Present address: Lilly Research Centre Ltd., Erl Wood Manor, Windlesham, Surrey GU20 6PH, UK.

'Present address: Department of Pharmacology, School of Medicine, University of California, San Francisco, CA 94143-0450.

Copyright (C) 1995 Society for Neuroscience $0270-6474 / 95 / 150135-09 \$ 05.00 / 0$
}

triphosphate $\left(\mathrm{IP}_{3}\right)$ synthesis. When expressed in Chinese hamster ovary $(\mathrm{CHO})$ cells, mGluR 1 also induces arachidonic acid release and activates adenylate cyclase (Aramori and Nakanishi, 1992). mGluR2, mGluR3, mGluR4, and mGluR6 inhibit the forskolin-stimulated accumulation of intracellular cyclic adenosine 3',5'-monophosphate (cAMP) (Nakanishi, 1992; Tanabe et al., 1992). An uncloned receptor with different pharmacology is also negatively coupled to adenylate cyclase in cultured striatal cells (Prézeau et al., 1992).

We previously observed that mGluR agonists activate a $\mathrm{Ca}^{2+}$ dependent $\mathrm{K}$ channel of large conductance (the big $\mathrm{K}$ channel) in mouse cerebellar granule cells maintained in culture (Fagni et al., 1991). This result was obtained in $\mathrm{Ca}^{2+}$-free medium and, therefore, corroborated previous biochemical studies showing that stimulation of mGluRs increases phosphoinositide production (Sladeczek et al., 1985; Nicoletti et al., 1986), which, in turn, releases $\mathrm{Ca}^{2+}$ from intracellular stores (Sugiyama et al., 1987). However, we observed that increasing the external $\mathrm{Ca}^{2+}$ concentration up to 5 or $10 \mathrm{~mm}$ enhanced the effect of the mGluR agonists (Fagni et al., 1991). This finding suggested that, in addition to the $\mathrm{IP}_{3}$ system, mGluR stimulation might also induce, directly or indirectly, $\mathrm{a} \mathrm{Ca}^{2+}$ influx.

It was therefore interesting to examine a possible mGluR modulation of voltage-dependent $\mathrm{Ca}$ channels as a mechanism for this $\mathrm{Ca}^{2+}$ influx in cerebellar granule cells. Of the various types of $\mathrm{Ca}$ channels that have been described in central neurons (for review, see Tsien et al., 1991; Ellinor et al., 1993), T-type (low-threshold, fast inactivating) Ca channels have been found to be absent from cerebellar granule cells (De Waard et al., 1991). In addition, since big $\mathrm{K}$ channels were recorded at relatively depolarized membrane potentials, and in a sustained manner, this suggests that if any voltage-dependent $\mathrm{Ca}$ channel was involved in the regulation of big $\mathrm{K}$ channels under these conditions, it could only correspond to mainly the high-threshold noninactivating $\mathrm{Ca}$ channels. In these neurons, two types of dihydropyridine (DHP)-sensitive channels display this property: L-type large-conductance channels (Slesinger and Lansman, 1991; Forti and Pietrobon, 1993), and a smaller-conductance $7 \mathrm{pS}$ channel (Bossu et al., 1994).

We found that mGluR agonists effectively induced opening of both DHP-sensitive calcium channels. For the L-type Ca channel, we show that this effect was not blocked but enhanced following pretreatment with pertussis toxin (PTX) or BAPTA$A M$, indicating that the excitatory ACPD effect was apparently mediated neither by a PTX-sensitive G protein nor by intracellular $\mathrm{Ca}^{2+}$. These observations are suggestive of an additional 
A

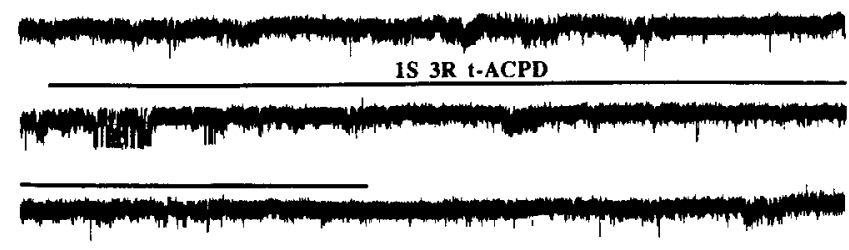

B

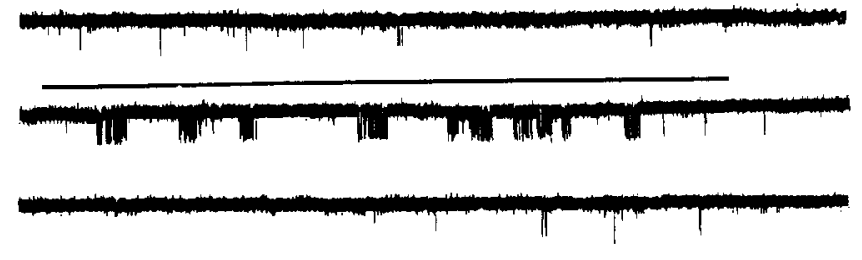

C

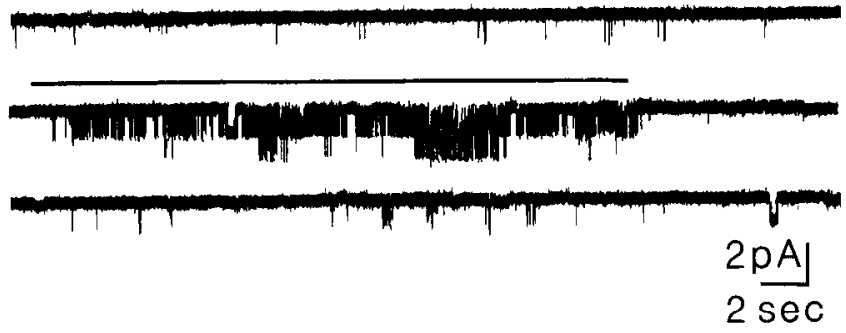

Figure 1. Effect of $100 \mu \mathrm{M} 1 S, 3 R$-ACPD on Ca channel activity: cellattached recordings obtained from three different mouse neurons bathed in physiological $\mathrm{NaCl}$ solution. The patch pipette potential was held at $-60 \mathrm{mV}$ (patch membrane potential $=0 \mathrm{mV}$, assuming cell resting membrane potential of $-60 \mathrm{mV}$ ). Horizontal lines represent agonist applications. Note the different patterns of $\mathrm{Ca}$ channel activity: an initial burst followed by a period of quiescence in $A$, successive burst separated by periods of quiescence in $B$, sustained activity in $C$. Calibration applies to $A-C$.

negative feedback normally exerted by both a PTX-sensitive G protein and $\mathrm{Ca}$ ions on this channel (Sayer et al., 1992; Fagni et al., 1993; Sahara and Westbrook, 1993).

Some of these results have been presented in abstract form (Bossu et al., 1993).

\section{Materials and Methods}

Cell preparation. Granule cells were isolated from the cerebellum of newborn mice or rats (PN 5-7), plated on poly-L-ornithine-coated petri dishes and grown in culture for 7-10 d as described elsewhere (Fagni et al., 1991, for mouse; De Waard et al., 1991, for rat). Culture media contained a relatively high concentration of $\mathrm{KCl}(30 \mathrm{~mm})$ to reduce glial cell outgrowth and improve neuronal survival.

Electrophysiology. Unitary currents were recorded using the cell-attached configuration of the patch-clamp technique; the external recording medium was free of added $\mathrm{Ca}^{2+}$ and either contained $0.1 \mathrm{mM}$ EGTA, $140 \mathrm{~mm} \mathrm{NaCl}, 4 \mathrm{~mm} \mathrm{MgCl}_{2}, 5 \mathrm{~mm} \mathrm{KCl}, 10 \mathrm{~mm}$ HEPES-Tris, $0.3 \mu \mathrm{M}$ tetrodotoxin, and $10 \mathrm{~mm}$ glucose, $\mathrm{pH} 7.4$ (mouse), or consisted of 140 mM K gluconate, $10 \mathrm{~mm}$ EGTA-KOH, $20 \mathrm{~mm}$ HEPES-KOH, $2 \mathrm{~mm}$ $\mathrm{MgCl}_{2}$, and $10 \mathrm{~mm}$ glucose, pII 7.4 (rat). Patch pipettes werc filled with an $110 \mathrm{~mm} \mathrm{BaCl} / 10 \mathrm{~mm}$ HEPES-Tris solution and (except where otherwise noted) contained $1 \mu \mathrm{M}$ Bay K 8644 to optimize unitary $\mathrm{Ca}^{2+}$ current recordings.

Recordings were performed at steady-state membrane potentials since these conditions, used to record mGluR-induced big K channel activation (Fagni et al., 1991), previously indicated mGluR-enhancement of $\mathrm{Ca}$ influx. Patch potentials given in the text were estimated assuming cell resting potentials of $-60 \mathrm{mV}$ and $0 \mathrm{mV}$ for cells bathed in the $\mathrm{NaCl}$ and $\mathrm{K}$ gluconate solutions, respectively.

Data analysis. Unitary current recordings were stored on videotape and analyzed off line. For analysis, current traces were filtered at 1.5 $\mathrm{kHz}$ with an 8-pole Bessel filter (Frequency Devices, Haverhill, MA), and sampled at $5 \mathrm{kHz}$ on a $20 \mathrm{MHz} P C 386 \mathrm{DW}$ computer. The threshold for detecting opening and closing transitions was set at $50 \%$ of the open level of each event, rejecting all events that did not exceed $0.5 \mathrm{msec}$ (i.e., less than two sampled points). Data were then converted to values corresponding to open times, closed times, and amplitudes. These values provided a way of calculating open probability $\left(N P_{v}\right)$, amplitude and open time distributions using the pCLAMP 5.5 software of Axon Instruments (Foster City, CA). Values of $N P_{o}$ were divided by the maximum number of open levels $(N)$ observed in each patch during the drug application, thus giving the value of the open probability $\left(P_{u}\right)$ for single channels. Mean amplitudes of unitary currents were calculated by fitting a Gaussian distribution, by the least squares method, to amplitude distribution histograms. Sums of decaying exponentials were fitted by least squares to each open time histogram. Data were expressed as means \pm SD from $n$ cells, and Student's $t$ tests were used for statistical analysis.

Drug applications. Drug solutions were prepared in the external solution ( $\mathrm{pH} \mathrm{7.4)} \mathrm{and} \mathrm{applied} \mathrm{outside} \mathrm{the} \mathrm{recorded} \mathrm{patch} \mathrm{of} \mathrm{membrane}$ (i.e., in the incubation bath), in the immediate vicinity of the cell, by means of a fast perfusion system described elsewhere (Fagni et al., 1991). Briefly, this consisted of a multibarrel system providing constant flow of solutions that could be switched from control to drug-containing solution in less than $30 \mathrm{msec}$. For some specific experiments, cells were incubated overnight with PTX $(500 \mathrm{ng} / \mathrm{ml})$ or for $30 \mathrm{~min}$ with BAPTAAM $(50 \mu \mathrm{M})$ previously prepared at $6 \mathrm{mM}$ in DMSO.

Materials. Glutamate receptor agonists AMPA ( $\alpha$-amino-3-hydroxy5-methyl-4-isoxazole propionate), NMDA ( $N$-methyl-D-aspartate), transACPD (trans-1-amino-cyclopentyl-1,3-dicarboxylate), L-AP3 [L(+)-2amino-3-phosphonopropionic acid], and L-AP4 [L(+)-2-amino-4-phosphonobutyric acid]; and antagonists CNQX (6-cyano-7-nitroquinoxaline-2,3-dione) and CPP $[( \pm)(2$-carboxypiperazine-4-yl)-propyl-1-phosphonic acid] were purchased from Tocris Neuramin (UK). BAPTAAM [bis( $o$-aminophenoxy)-ethane- $N, N, N^{\prime}, N^{\prime}$-tetraacetic acid, tetra(acetoxymethyl)-ester] was from Calbiochem, and pertussis toxin (PTX), from List Biochemical Laboratories (USA). L-CCG 1 [(2S, $\left.{ }^{\prime} S, 2^{\prime} S\right)$-2-(carboxycyclopropyl)glycine] was a gift of Dr. H. Shinozaki (The Tokyo Metropolitan Institute of Medical Science, Tokyo, Japan) and the $1 S, 3 R$ - and $1 R, 3 S$-ACPD isomers were gifts of Dr. K. Curry (University of British Columbia, Department of Physiology, Vancouver, Canada).

\section{Results}

\section{Activation of Ca channels by mGluR agonists}

When the patch pipette potential was maintained at depolarized potentials $(-30 \mathrm{mV}$ up to $0 \mathrm{mV})$, bath application of the selective mGluR agonist $1 S, 3 R$-ACPD $(100 \mu \mathrm{M})$ (Fig. 1) or the racemic trans-ACPD evoked an increase in Ca channel activity in rodent cerebellar neurons, with no difference found between cells from rat or mouse. The agonist-induced increase in $\mathrm{Ca}$ channel activity was variable between patches, both in terms of onset latency and pattern of channel opening. Latency varied from less than $1 \mathrm{sec}$ to $25 \mathrm{sec}$ (mean $8.9 \pm 8.6 \mathrm{sec}, n=15$ ). Responses varied from an initial burst-like activity interrupted by periods of quiescence in the continued presence of agonist (Fig $1 A, B$ ), to a response that was sustained for the entire period of agonist application ( $30 \mathrm{sec}$ to $2 \mathrm{~min}$; Fig. 1C).

An excitatory effect occurred in the presence of $1 \mu \mathrm{M}$ Bay $\mathrm{K}$ 8644. As illustrated, trans-ACPD added to the bath induced an increase Ca channel activity, regardless of whether the patches were recorded in conditions where the cell was hyperpolarized ( $\mathrm{NaCl}$ solution; Fig. 1) or depolarized (isotonic $\mathrm{K}$ gluconate solution; e.g., Fig. $2 A$ ).

Application of trans-ACPD $(100 \mu \mathrm{M})$ or its isomers (100-500 $\mu \mathbf{M})$ was effective in eliciting an increase in Ca channel activity, 

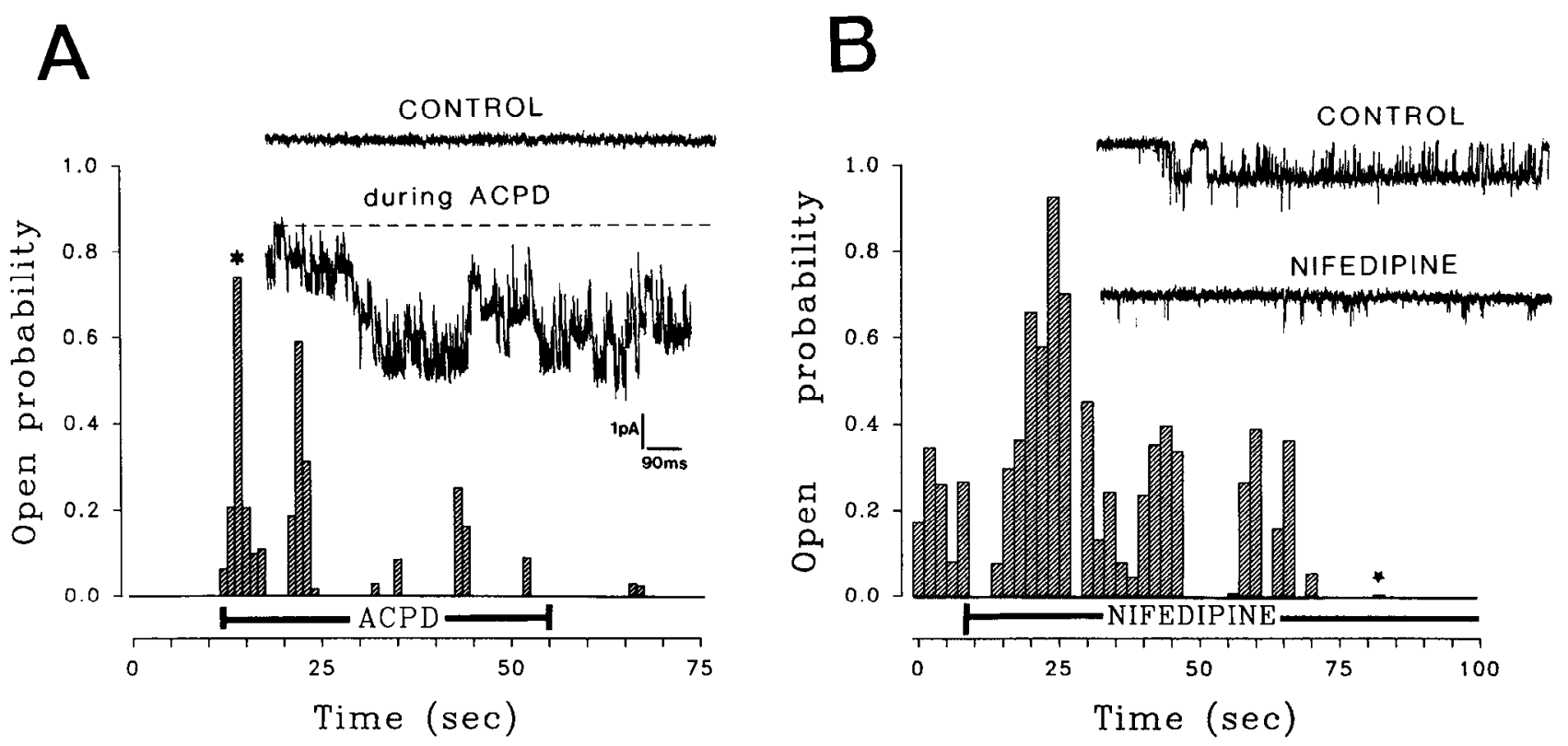

Figure 2. Activation of L-type channel by trans-ACPD: patch yielding unitary Ca channel activity. $A$ and $B$ show open probability histograms as a function of recording time for unitary $\mathrm{Ca}$ channel activity in control and during drug application. $A$, Ca channel activity is induced by $100 \mu \mathrm{M}$ trans-ACPD (applied during har) at a $-30 \mathrm{mV}$ holding potential at which no Ca channel activity was recorded in control conditions (amplitude of single events $=-1.45 \mathrm{pA}$; note the presence of three channels on the patch). $B$, On the same patch, the same Ca channel is now activated by depolarizing the membrane potential to $-20 \mathrm{mV}$, and $1 \mu \mathrm{M}$ nifedipine (applied during bar) blocks this activity (mean amplitude of elementary events $=-1.10 \mathrm{p \Lambda}$ ). Insets illustrate traces obtained in control conditions (upper traces) and in the presence of the drug (lower traces), taken at the times indicated by the asterisks. Cell attached conditions on a rat granule cell bathed in isotonic $\mathrm{K}$ gluconate solution.

increasing open probability $P_{0}$ from $0.015 \pm 0.02$ to $0.52 \pm 0.2$ $(n=3)$ for trans-ACPD and from $0.03 \pm 0.03(n=8)$ to 0.62 $\pm 0.24(n=5)$ with $1 R, 3 S$-ACPD, and to $0.64 \pm 0.06(n=5)$ with $1 S, 3 R$-ACPD, respectively (Fig. $3 A, B$ ) within the initial drug-induced burst of activity. If the $P_{o}$ in the presence of transACPD is calculated over the entire duration of drug application, it is reduced because of the silent periods to $0.062 \pm 0.03(n=$ 4). The nonselective mGluR agonists glutamate (1 $\mathrm{mm})$ and quisqualate $(50 \mu \mathrm{M})$, in the presence of $10 \mu \mathrm{M} \mathrm{CPP}$ and/or 50 $\mu \mathrm{M}$ CNQX to block ionotropic glutamate receptors, also increased the $\mathrm{Ca}$ channel activity, increasing open probability from $0.03 \pm 0.06(n=8)$ to $0.75 \pm 0.14(n=8)$ and $0.58 \pm$ $0.23(n=5)$, respectively, again during the initial bursts. Examples of such effects are shown in Figure 4. The tested mGluR agonists (both enantiomers and racemic trans-ACPD, glutamate, and quisqualate) were effective in increasing $\mathrm{Ca}$ channel activity in 13 of 31 patches $(42 \%)$ that displayed $\mathrm{Ca}$ channel openings before agonist application. Neither L-AP3 ( $1 \mu \mathrm{M}, n=$ 5), L-AP4 (1 $\mu \mathrm{M}, n=10)$, L-CCG1 $(1 \mu \mathrm{M}, n=10)$, nor AMPA (50 $\mu \mathrm{M}, n=5)$ or NMDA $(100 \mu \mathrm{M}, n=5)$ in the presence of the ionotropic receptor antagonists activated $\mathrm{Ca}$ channels (data not shown).

Note that in all cases where basal activity was observed, application of a glutamate metabotropic agonist did not modify the amplitude of the activity. This suggests that the metabotropic agonist had no effect on the membrane potential.

Attempts to characterize the ACPD response on macroscopic Ba currents in whole-cell recording conditions failed in most cases, although trans-ACPD was found to increase the wholecell $I_{\mathrm{Ba}}$ in a small number of cells (data not shown). This suggests that the intracellular messenger involved in this response is readily diffusible and lost during dialysis of the cell by the recording pipette solution.

\section{Characterization of the Ca channel positively coupled to mGluR}

The channel activated by trans-ACPD was characterized both by its pharmacology and its conductance. On the cell illustrated
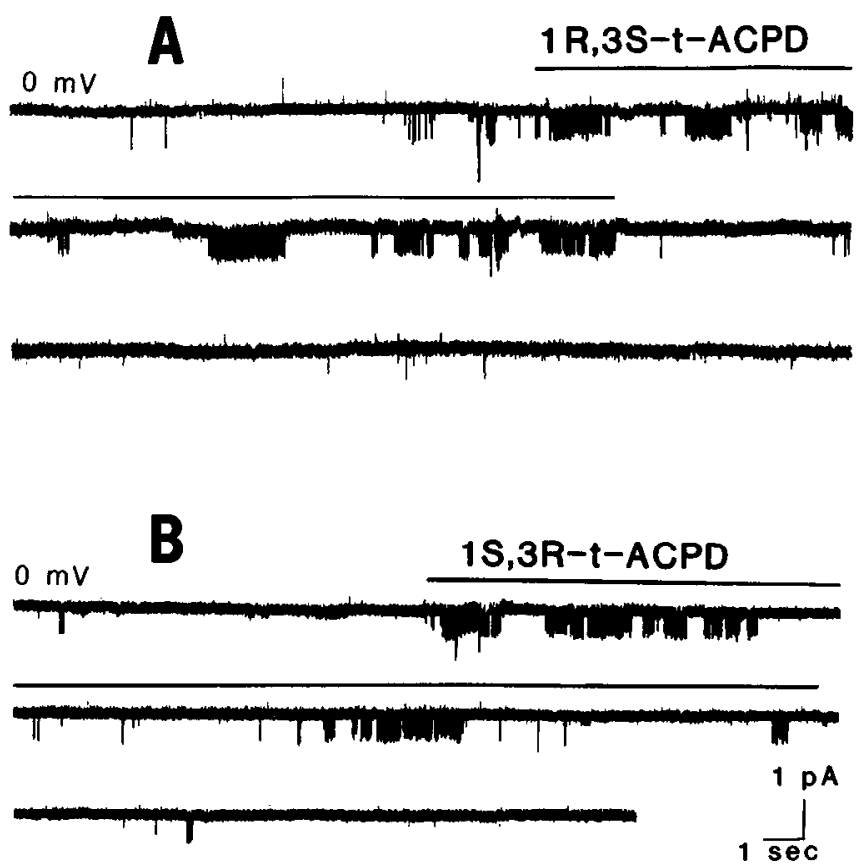

Figure 3. Effects of $500 \mu_{\mathrm{M}}$ ACPD isomers on Ca channel activity. Horizontal lines represent the indicated agonist applications. $A$ and $B$ were obtained from two different cell-attached patches at $0 \mathrm{mV}$ membrane potential, from mouse granule cells bathed in physiological $\mathrm{NaCl}$ solution. 

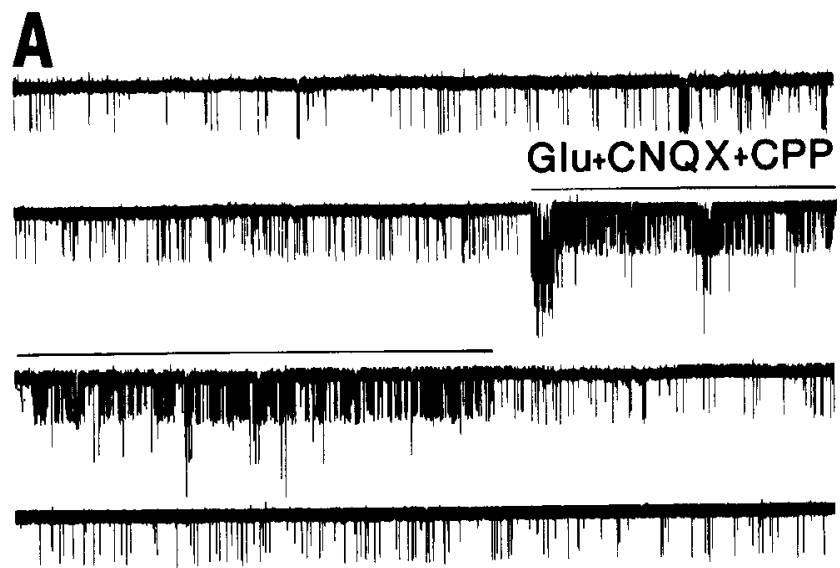

B
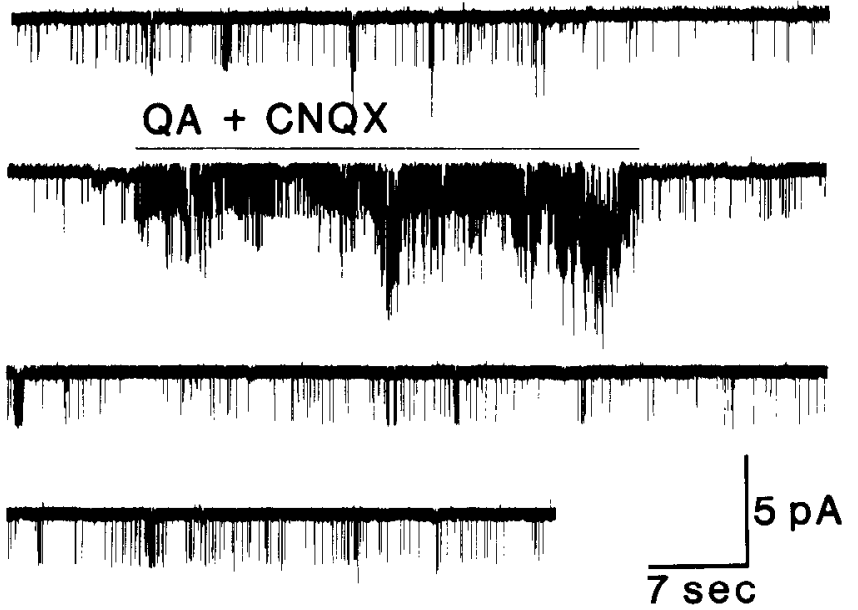

Figure 4. Effects of nonselective glutamate agonists on unitary Ca channel activity at $-30 \mathrm{mV}$. Metabotropic activity was selected in $A$ by coapplication of $50 \mu \mathrm{M} \mathrm{CNQX}$ and $10 \mu \mathrm{M}$ CPP with $1 \mathrm{~mm}$ glutamate and in $B$ by $50 \mu \mathrm{M}$ CNQX with $50 \mu \mathrm{m}$ quisqualate. Recordings were obtained from the same cell-attached patch, which also responded to $500 \mu \mathrm{M} 1 S, 3 R$-ACPD, from mouse granule cells bathed in physiological $\mathrm{NaCl}$ solution.

in Figure 2, when the membrane potential was maintained just below the threshold for activation of the channel $(-30 \mathrm{mV}$ in this case), trans-ACPD evoked bursting activity at the beginning of drug application (see induced changes in $P_{n}$ on lower graph in Fig. 2A). Activity of such a channel could be increased by further depolarization to $-15 \mathrm{mV}$ (Fig. $2 B$ ), and abolished by an external application of the DHP antagonist, nifedipine (1 $\mu \mathrm{M})$. The conductance of this channel, estimated between -35 and $-10 \mathrm{mV}$, was equal to $24 \mathrm{pS}$ (data not shown). The mean chord conductance of the $\mathrm{Ca}$ channel activated by the various mGluR agonists was $25 \pm 3 \mathrm{pS}(n=11)$, in the absence and presence of $\mathrm{mGluR}$ agonists. Finally, this channel displayed two open times characterized by the following time constants $\tau_{1}=$ $0.77 \pm 0.25 \mathrm{msec}$ and $\tau_{2}=4.62 \pm 0.90 \mathrm{msec}$ with a weight ratio $W_{1} / W_{2}$ of $1.59 \pm 0.57(n=8)$. These kinetic properties were similar to those obtained in the absence of drug $\left(\tau_{1}=0.80\right.$ $\pm 0.06 \mathrm{msec}, \tau_{2}=4.88 \pm 0.85 \mathrm{msec},{ }_{w} 1 / W_{2}=2.15 \pm 1.48, n$

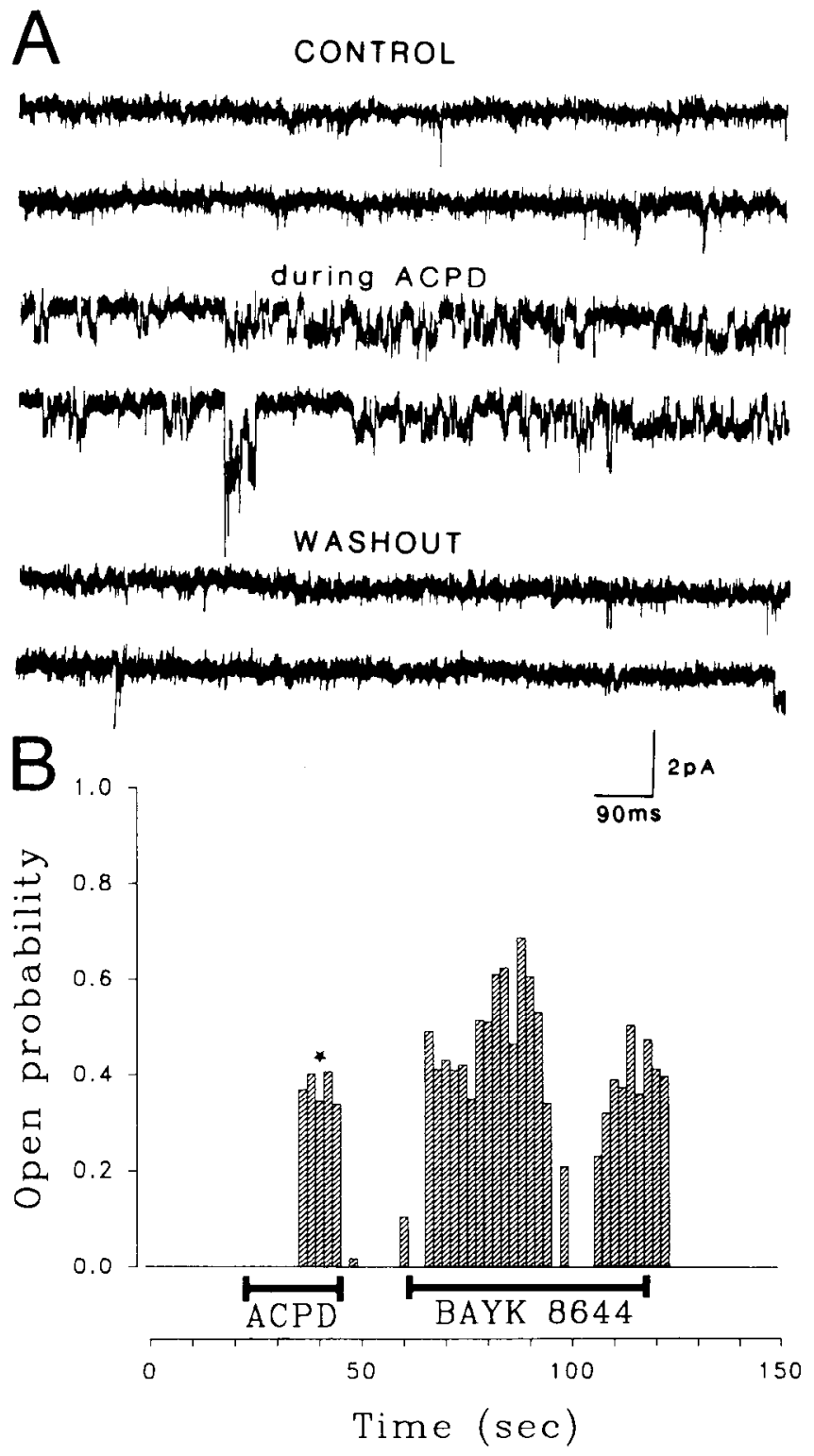

Figure 5. Effects on trans-ACPD on the $7 \mathrm{pS}$ DHP-sensitive Ca channel activity. $A$, Unitary currents $(0.7 \mathrm{pA}$ mean amplitude) recorded from a cell-attached patch at a steady-state patch potential of $-10 \mathrm{mV}$, during application of $100 \mu \mathrm{M}$ trans-ACPD. Note that this channel activity corresponds to a $7 \mathrm{pS} \mathrm{DHP-sensitive} \mathrm{Ca} \mathrm{channel.} \mathrm{Recordings} \mathrm{were}$ obtained from a rat granule cell bathed in isotonic $\mathrm{K}$ gluconate solution and without Bay $\mathrm{K} 8644$ in the pipette solution. $B$, Open probability histogram as a function of recording time for the same patch as in $A$. Asterisk points to the recording period illustrated in $A$. Note also the pronounced increase in $P_{o}$ during application of $1 \mu \mathrm{M}$ Bay K 8644 to the cell body.

$=7$ ) (data not shown). These properties are characteristic of the classical L-type Ca channels identified in cerebellar granule cells (Feltz et al., 1990; Slesinger and Lansman, 1990, 1991; Forti and Pietrobon, 1993).

In addition to this classical L-type Ca channel activity, cerebellar granule cells possess a $7 \mathrm{pS}$ Ca channel that is also sensitive to DHPs (Feltz et al., 1990; Bossu et al., 1994). In four patches where this activity was recorded in isolation, we observed that it was also increased during trans-ACPD applications (Fig. 5). This effect was not characterized further. 
A
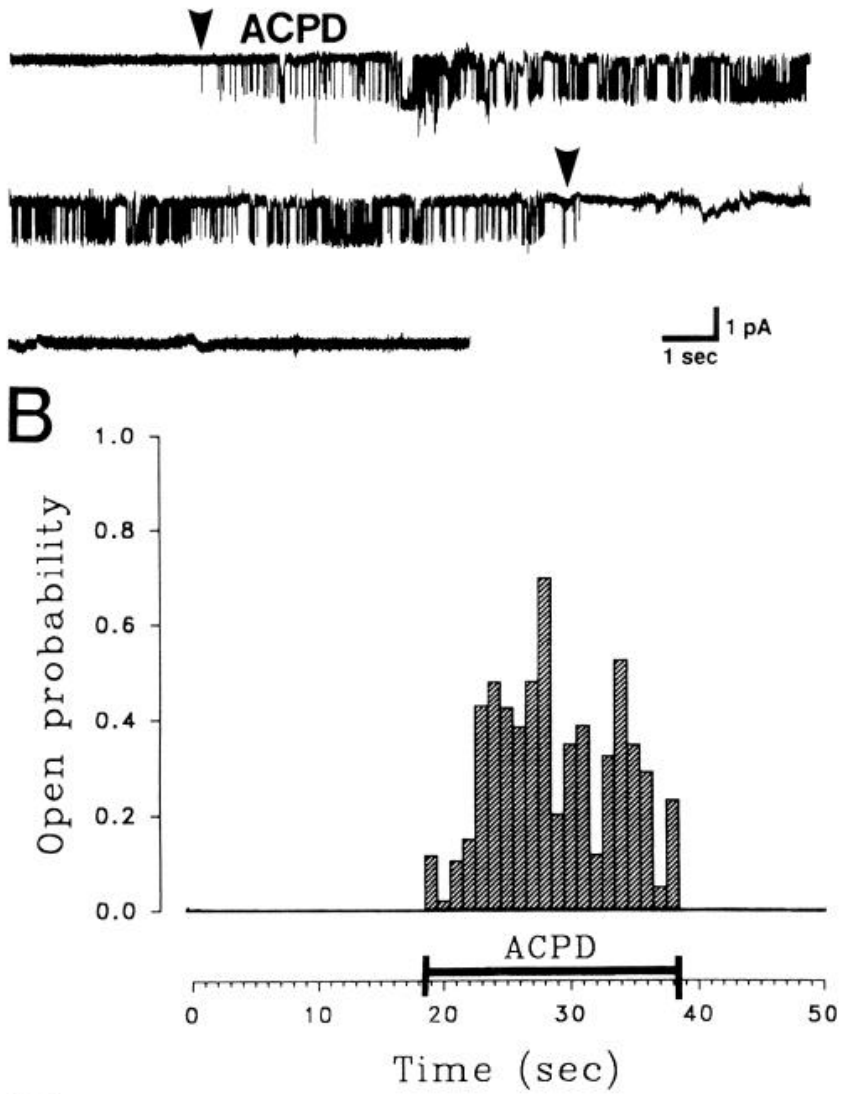

C

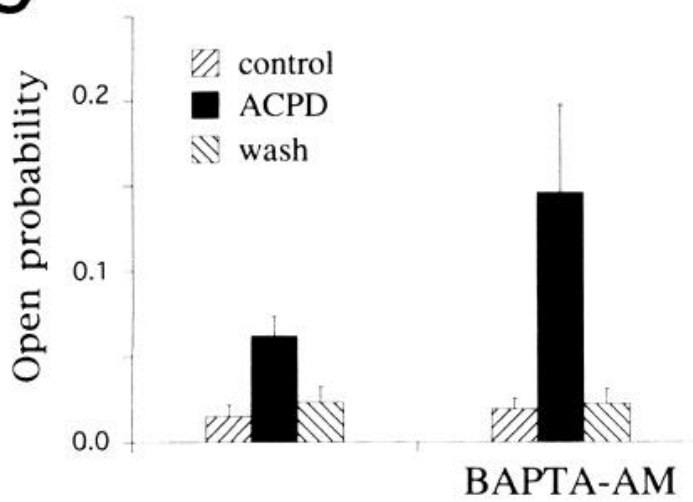

Figure 6. Effect of BAPTA-AM on the activation of Ca channel by mGluR: continuous cell-attached recording obtained from a rat cerebellar neuron previously loaded with BAPTA-AM. A, Successive traces of the activity recorded in control conditions and during an application of $100 \mu \mathrm{m}$ trans-ACPD (between arrowheads), recorded with the cell bathed with isotonic potassium gluconate. The patch membrane potential was $-5 \mathrm{mV}$. $B$, Corresponding open probability histogram. Note that, in this condition, the activity is maintained through the ACPD application. $C$, Comparison of the ACPD effect without and with a BAPTA-AM preincubation. Open probability was measured on eight cells in each case that displayed a similar activity before ACPD application. Height of each column shows mean value in each case, and error bars, the corresponding SE.

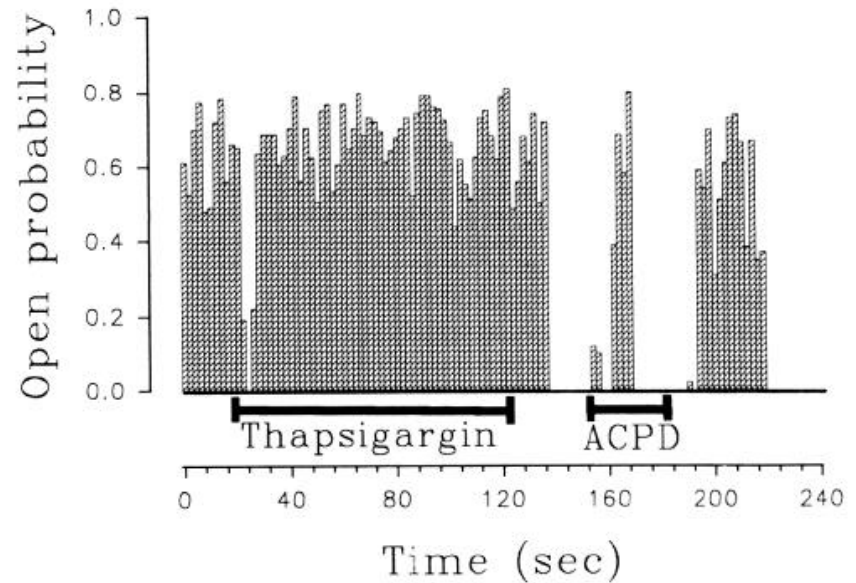

Figure 7. Effect of trans-ACPD on Ca channel open probability following thapsigargin treatment: patch containing a single L-type channel activity, recorded from a rat cell pretreated with BAPTA-AM $(50 \mu \mathrm{M}$ for $30 \mathrm{~min}$ ) and then bathed in isotonic $\mathrm{K}$ gluconate solution. In this condition, the open probability histogram of a $-1.28 \mathrm{pA}$ elementary event induced at $0 \mathrm{mV}$ as a function of time shows a delayed effect of thapsigargin ( $1.5 \mu \mathrm{M}$ applied during bar $)$ since blockade of the Ca channel activity only occurred after its washout, and this effect was reversible. Note that trans-ACPD $(100 \mu \mathrm{M})$ is still efficacious though stores have been depleted.

\section{Effect of internal $\mathrm{Ca}^{2+}$}

Since stimulation of mGluRs coupled to phosphoinositides increases $\left[\mathrm{Ca}^{2+}\right]_{i}$ (Sladeczek et al., 1988, for a review) and because intracellular $\mathrm{Ca}^{2+}$ has been shown to control $\mathrm{Ca}^{2+}$ currents in GH3 cells (Kalman et al., 1988), cultured sensory neurons (Bossu et al., 1989) and ventricular myocytes (Yue et al., 1990), we examined whether the action of trans-ACPD on the studied Ca channel was affected by internal $\mathrm{Ca}^{2+}$. Cells were pretreated with the membrane-permeant $\mathrm{Ca}^{2+}$ chelator BAPTA-AM to buffer $\left[\mathrm{Ca}^{2+}\right]_{i}$. After the BAPTA-AM treatment, trans-ACPD $(100 \mu \mathrm{M})$ was found to activate the $\mathrm{Ca}$ channel increasing open probability from $0.023 \pm 0.016$ in control to $0.15 \pm 0.13(n=8)$ during the entire ACPD application. Moreover, the number of patches responding was found to increase to $80 \%$ versus $40 \%$ in the absence of BAPTA (12 of 15 cells tested from two separate cultures of rat cells) and the enhanced activity was more sustained during the trans-ACPD application (Fig. $6 A, B$ ). The latter was reflected by the higher increased open probability when measured over the entire ACPD application period: $0.15 \pm 0.13$ $(n=8)$ compared to $0.062 \pm 0.03(n=8)$ without BAPTA pretreatment (Fig. $6 \mathrm{C}$ ). This enhancement of activity observed in the presence of BAPTA suggests that $\mathrm{Ca}^{2+}$ released from $\mathrm{IP}_{3}$ sensitive stores is not the messenger involved in the activation of the L-type channels. On the contrary, this suggests that internal calcium exerts an inhibitory control on the effect of transACPD on this channel.

The next question addressed was whether or not the level of calcium in the $\mathrm{IP}_{3}$-sensitive stores exerts a control on the influx of $\mathrm{Ca}^{2+}$ through L-type channels. To test this idea, stores were first depleted by external application of thapsigargin, and then trans-ACPD was applied. Following application of $1.5 \mu \mathrm{M}$ thapsigargin, an irreversible blockade of the L-type channel activity was observed as expected from an increased internal $\mathrm{Ca}^{2+}$ concentration. Under this condition, trans-ACPD was not able to induce $\mathrm{Ca}$ channel activity ( $n=6$ not illustrated). To prevent an inhibitory thapsigargin effect mediated by $\mathrm{Ca}$ ions, cells were 
A

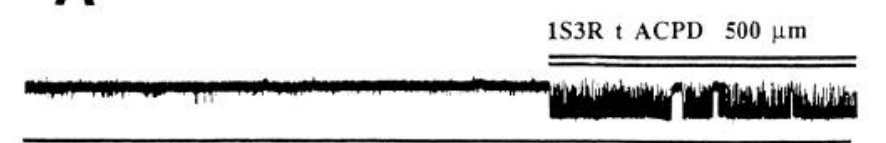

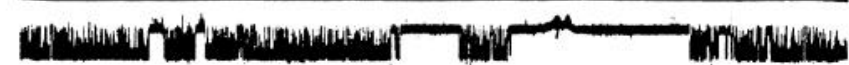

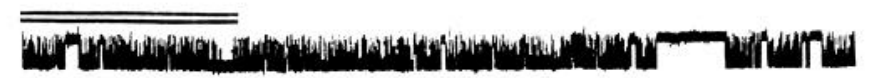

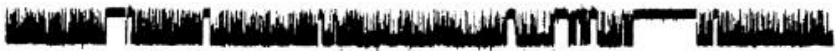
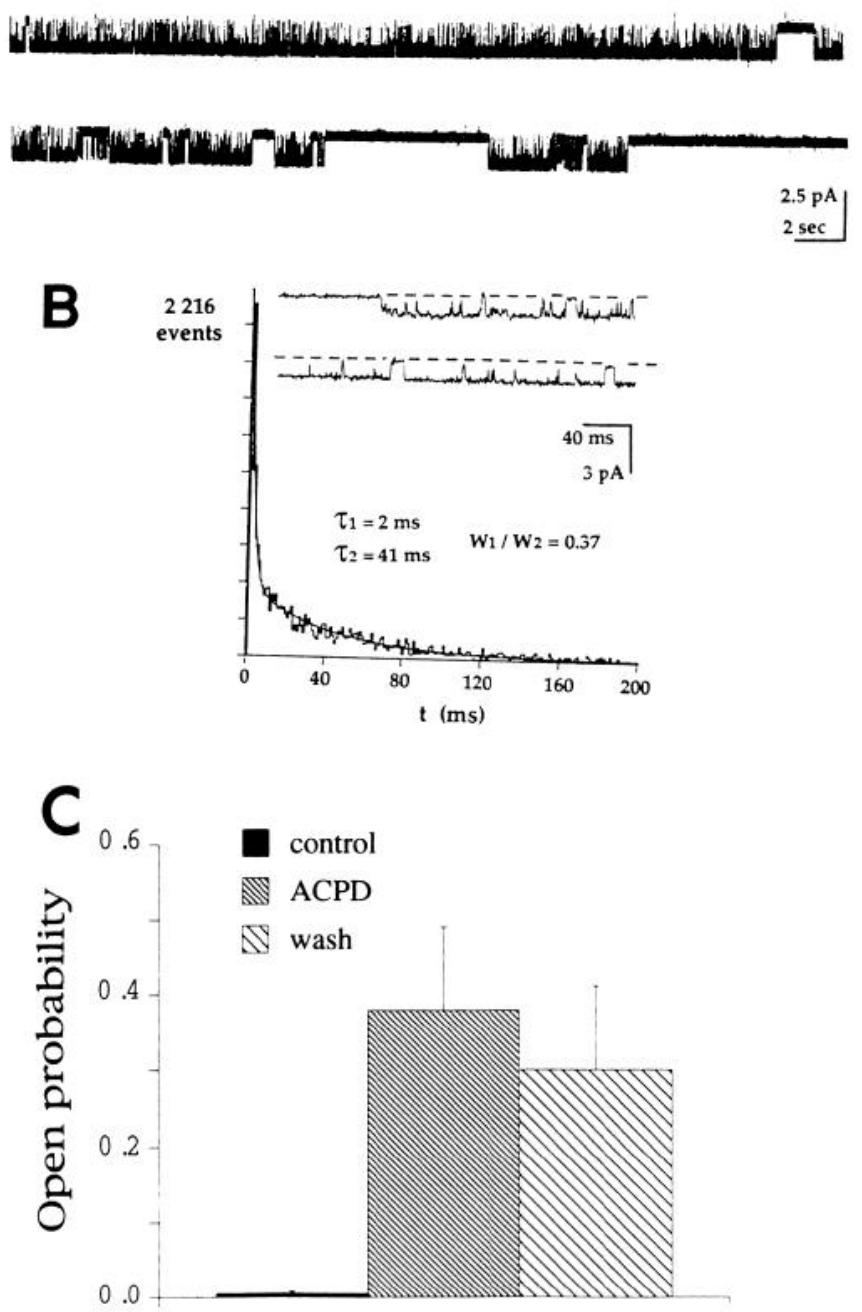

Figure 8. Effects of PTX on the action of trans-ACPD. A and Ca channel activity at a steady-state membrane potential of $0 \mathrm{mV}$ and recorded from a cell pretreated with $500 \mathrm{ng} / \mathrm{ml}$ PTX. $B$, Characteristics of the open times of the channel activity shown in $A$. The dashed line represents the closed state of the channel. The open time histogram fitted the following double exponential: $y=670 \exp (-t / 2)+1863$ $\exp (-t / 41)$. Recordings were obtained from a mouse granule cell bathed in physiological $\mathrm{NaCl}$ solution. $C$ shows the open probability after PTX treatment estimated in eight cells (where the holding potential was set at a just subthreshold value to elicit a $\mathrm{Ca}$ channel activity in control conditions) during ACPD application and 1 min after wash. Note by comparison with Figure 5 that the ACPD effect is now prolonged. Height of each column shows mean value, and error bars, SD. pretreated by BAPTA-AM. In this case $(n=10)$, the effect of thapsigargin on the $\mathrm{Ca}$ channels was less potent and delayed, and now reversible (Fig. 7). In these conditions, trans-ACPD was still able to increase $\mathrm{Ca}$ channel activity to an extent similar to that observed without thapsigargin pretreatment. This suggests that the ACPD response is not controlled by the $\mathrm{Ca}^{2+}$ level in the stores.

\section{Effect of pertussis toxin on the Ca channel}

Finally, an attempt was made to characterize the $\mathrm{G}$ proteinmediating this response. The effects of preincubating the cells with PTX $(500 \mathrm{ng} / \mathrm{ml})$ overnight, were studied on the action of both trans-ACPD enantiomers. A similar PTX-treatment has previously been shown to result in ADP-ribosylation of $\mathrm{G}_{\mathrm{i}}$ and $G_{o}$ in neurons (Prézeau et al., 1992). This treatment did not block the action of either $1 S, 3 R$-ACPD or $1 R, 3 S$-ACPD (Fig. 8). The PTX treatment even enhanced the effects of ACPD in two ways: activation of the $\mathrm{Ca}$ channels persisted during washout of the agonist (Fig. $8 A, C$ ) and the mean open time significantly increased $\left(\tau_{1}=3.72 \pm 1.9 \mathrm{msec}, \tau_{2}=23 \pm 11 \mathrm{msec}, W_{1} /\right.$ $W_{2}=10.07 \pm 0.8, \mathrm{n}=5$ (Fig. $8 B$; compared to $\tau_{1}=0.77 \pm$ $0.25 \mathrm{msec}$ and $\tau_{2}=1.62 \pm 0.90 \mathrm{msec}, W_{1} / W_{2}$ of $1.59 \pm 0.57$, $n=8$, in control conditions). The PTX pretreatment also increased to $73 \%$ (16 of 22 patches) the proportion of patches responding to ACPD (instead of $42 \%$ ). This indicates that PTXsensitive $G$ proteins mediate an inhibitory control in this system.

\section{Discussion}

Our results show that glutamate receptors are positively coupled to $\mathrm{Ca}$ channels in cerebellar granule cells maintained in culture. In this cell type, various $\mathrm{Ca}$ channels have been shown to be present. We show that this positive coupling exists between glutamatergic receptors and a complex family of DHP-sensitive channels. The pharmacology of the effect indicates that solely mGluRs are involved.

\section{Mediation of glutamate-induced activation of $\mathrm{Ca}$ channels by a metabotropic receptor}

Glutamate is known to exert a positive control on voltage-dependent $\mathrm{Ca}^{2+}$ entry, mainly through the depolarizing effects mediated by ionotropic receptors. We describe here a glutamateenhanced $\mathrm{Ca}$ channel activity that was observed when the membrane potential of the cells was zeroed by bathing the cells in isotonic $\mathrm{K}^{+}$. Further, when recordings were made when the cell membrane potential was polarized by bathing the cells in $\mathrm{NaCl}$, the amplitude of the activated channel was identical before and during agonist application, thus excluding the possibility that this activation resulted from depolarization of the cell. The hypothesis of a direct action on Ca channels is ruled out by the fact that, in the cell-attached recording configuration, the recorded channel is isolated from the bath by the tight seal between the membrane and the patch pipette. Taken together, these observations imply that a diffusible second messenger was involved in $\mathrm{Ca}$ channel activation by a metabotropic receptor.

Our results suggest that $m$ GluR 1 and/or mGluR5 are the receptor(s) transducing the response. This hypothesis is first supported by our pharmacological observations. Quisqualic acid is the most active agonist on mGluRs coupled to phospholipase $\mathrm{C}$ and almost inactive on mGluRs negatively coupled to adenylate cyclase (Manzoni et al., 1990; Nakanishi, 1992). In our experiments, quisqualate activated $\mathrm{Ca}$ channels. By contrast, 
neither L-CCG1 nor L-AP4 mimicked this facilitatory effect. Also, both $1 S, 3 R$ - and $1 R, 3 S$-ACPD equally activated these channels, at concentrations that have been shown to stimulate inositol phosphate formation and increase $\left[\mathrm{Ca}^{2+}\right]_{i}$ (Manzoni et al., 1993). Third, the involvement of mGluRs inhibiting cAMP production (i.e., mGluR2, mGluR3, and mGluR4; Nakanishi, 1992 ) is unlikely since cAMP has been shown to upregulate $\mathrm{Ca}$ channcls in neurons (Gray and Johnston, 1987; Chetkovich et al., 1991) and because of the PTX insensitivity of the presently observed ACPD effects.

\section{Activation of DHP-sensitive Ca channels}

In cerebellar granule cells, various $\mathrm{Ca}$ channels have been identified (Feltz et al., 1990; Slesinger and Lansman, 1990). The family of dihydropyridine-sensitive channels, not inactivated by a steady-state depolarization, is complex; it includes, in addition to a series of L-type ( $24 \mathrm{pS}$ ) channels with distinct gating properties (Slesinger and Lansman, 1991; Forti and Pietrobon, 1993), a small 7 pS channel (Bossu et al., 1994). We show that glutamatergic metabotropic receptors are positively coupled to both the small and the large-conductance $\mathrm{Ca}$ channels (see also Zegarra-Moran and Moran, 1993, for such a facilitatory effect of glutamate on the $\mathrm{Ca}^{2+}$ L-type channel in the same cells). An increase in $\mathrm{Ca}^{2+}$ current following stimulation of mGluRs has also been recently observed in chick dorsal root ganglion and rat hippocampal neurons (Mironov and Lux, 1992). Due to the steady-state depolarization protocol that was employed in the present experiments, similar effects on the other types of $\mathrm{Ca}$ channels present in these neurons would have escaped our investigations. Our experiments show that mGluRs can be positively coupled to L-type channels, in addition to the negative coupling previously described (Sayer et al., 1992; Sahara and Westbrook, 1993).

\section{Heterogeneity of metabotropic responses}

Two questions then arise: first, are the two types of control present on cerebellar granule cells, and second, is the activation of different receptors and/or distinct receptor-effector couplings involved? We show here that metabotropic glutamate receptors exert a facilitatory effect on $\mathrm{Ca}$ channels, probably mediated by mGluR1/mGluR5.

The PTX insensitivity implies that none of the $G_{i} / G_{n}$ proteins are involved in the mGluR-enhanced $\mathrm{Ca}$ channel activity. A negative coupling between mGluRs and L-type Ca channels via a $G_{0}$-like protein is not excluded by the present study, however, and might account for the prolonged trans-ACPD stimulatory effects following PTX treatment. Such a PTX-sensitive inhibitory effect is involved when L-type Ca channels of cerebellar granule cells are transiently activated by step depolarizations (Fagni et al., 1993). In contrast to the facilitation effect described here, it is mimicked by L-CCG1 and is PTX sensitive (Chavis et al., in press). Also, inhibition of $\mathrm{Ca}^{2+}$ current following stimulation of mGluRs has been observed in hippocampal (Lester and Jahr, 1990; Swartz and Bean, 1992) and neocortical neurons (Sayer et al., 1992). The latter effect is likely coupled by a $\mathrm{G}_{\mathrm{o}}$ like protein. It has been clearly established that $G_{0}$, a pertussis toxin-sensitive $\mathrm{G}$ protein, negatively controls L-type $\mathrm{Ca}$ channels in neuroblastoma glioma hybrid cells (Hescheler et al., 1987) and anterior pituitary cells (Lledo et al., 1992), and may do so in adrenal chromaffin cells (Kleppisch et al., 1992; see Schultz et al., 1990, for a review). Brabet et al. (1988) have shown that $G_{0}$ is expressed in cerebellar granule cells. The nu- merous mGluR subtypes already described make it probable that more than one $\mathrm{G}$ protein is involved in the regulation of the L-type Ca channels. This has already been shown to be the case for muscarinic receptors acting on N-type $\mathrm{Ca}$ channels (Beech et al., 1992). The present study and the work of Chavis et al. (in press) is the first report of two distinct effects resulting from the activation of glutamate metabotropic receptors on a single cell type.

\section{Messengers involved in the metabotropic response}

Both mGluR 1 and mGluR5 are positively coupled to phospholipase C (Nakanishi, 1992) and are expressed in cerebellar granule cells (Abe et al., 1992; Bessho et al., 1993). Since wholecell $\mathrm{Ca}^{2+}$ currents in cerebellar granule cells can be upregulated by the $\mathrm{IP}_{3}$ pathway (De Waard et al., 1992), one must consider here the possibility that either $\mathrm{IP}_{3}$ or an $\mathrm{IP}_{3}$-induced release of intracellular $\mathrm{Ca}^{2+}$ may be involved in the presently observed response. Buffering intracellular $\mathrm{Ca}^{2+}$ with BAPTA did not block the coupling between mGluRs and $\mathrm{Ca}$ channels. Therefore, the action of mGluR agonists was not directly mediated by internal $\mathrm{Ca}^{2+}$, suggesting a direct action of $\mathrm{IP}_{3}$ on $\mathrm{Ca}$ channels. However, the involvement of another second messenger cannot be excluded.

Given the previously reported sensitivity of L-type Ca channels to intracellular $\mathrm{Ca}^{2+}$ (Kalman et al., 1988; Bossu et al., 1989; Yue et al., 1990) and the rise in $\left[\mathrm{Ca}^{2+}\right]_{i}$ during mGluR agonist application (Fagni et al., 1991), one would expect $\mathrm{Ca}^{2+}$ released by $\mathrm{mGluR} 1 / \mathrm{mGluR} 5$ stimulation to inhibit, rather than stimulate, these channels. Indeed, the potentiation of transACPD effects following BAPTA-AM pretreatment could be explained by the removal of such an intraccllular $\mathrm{Ca}^{2+}$-mediated inhibition of $\mathrm{Ca}$ channels.

In a number of cell types, enhanced influx of $\mathrm{Ca}^{2+}$ is triggered or modulated by the emptying of intracellular stores (for a short review, see Clapham, 1993). Since trans-ACPD is known to release $\mathrm{Ca}^{2+}$ from internal stores, it is possible that the observed enhancement of $\mathrm{Ca}$ channel activity depends on the efflux of $\mathrm{Ca}^{2+}$ from, or the $\mathrm{Ca}^{2+}$ content of, these stores. Assuming that the thapsigargin treatment completely emptied the internal IP $_{3}$ sensitive stores, one would expect that thapsigargin should enhance the trans-ACPD-induced channel activity if the latter depends on the $\mathrm{Ca}^{2+}$ content of the stores. Since the thapsigargin treatment never directly provoked such an effect even following BAPTA-AM treatment, $\mathrm{Ca}^{2+}$ efflux per se from the store or the filling state of the stores is unlikely to be the signal responsible for stimulating the enhanced $\mathrm{Ca}$ channel activity.

Even though the second messenger responsible for $\mathrm{Ca}$ channel activation has not been identified, it seems to be produced in the vicinity of its target. This is suggested by the observation of delays of less than $1 \mathrm{sec}$ between the time when drug application was started and the beginning of the response. Similar short delays have been observed for the coupling of muscarinic and glutamatergic metabotropic receptors and $\mathrm{Ca}$ channels (Beech et al., 1992; Bernheim et al., 1992; Sahara and Westbrook, 1993). The present facilitatory effect could rarely be observed in whole-cell recording conditions. The latter observation implies that the second messenger is highly diffusible. However, we cannot exclude the possibility that whole-cell recording conditions could have modified the characteristics of the L-type Ca current itself.

The present article describes a positive coupling between glutamatergic receptors and $\mathrm{Ca}$ channels. It therefore corroborates 
previous observations suggesting that an influx of $\mathrm{Ca}^{2+}$ participates in the mGluR-induced increase in $\left[\mathrm{Ca}^{2+}\right]_{l}$. Thus, increased external $\mathrm{Ca}^{2+}$ (Fagni et al., 1991; Abe et al., 1992) or depolarization with high external $\mathrm{K}^{+}$concentrations enhanced mGluR-induced increases in $\left[\mathrm{Ca}^{2+}\right]_{l}$, while reduced $\left[\mathrm{Ca}^{2+}\right]_{o}$ decreased mGluR-induced increases in $\left[\mathrm{Ca}^{2+}\right]_{i}$ (Guiramand et al., 1991). This indicates that the $\mathrm{Ca}$ and $\mathrm{K}$ channel proteins and also the metabotropic receptor are closely associated in the membrane. A functional triplet, constituting an $m$ GluR in the vicinity of depolarizing $\mathrm{Ca}$ channels and hyperpolarizing $\mathrm{Ca}^{2+}$ gated $\mathrm{K}$ channels, could play an important role in the control of cell firing as suggested by the following observations. Membrane potential oscillations in sympathetic preganglionic neurons (Spanswick et al., 1992) and burst firing in dorsolateral septal nucleus neurons follow mGluR activation (Zheng and Gallagher, 1992). The latter response was inhibited by Ca channel blockers, suggesting that an influx of external $\mathrm{Ca}^{2+}$ was required for this mGluR-mediated activity. In synaptic regions, metabotropic mGluR have been shown to participate in processes of synaptic plasticity such as long-term potentiation (McGuinness et al., 1991; Bortolotto and Collingridge, 1992) and long-term depression (Ito and Karachot, 1990). Long-term changes in synaptic efficacy involve $\mathrm{Ca}^{2+}$-dependent processes and, therefore, might also depend upon the presently observed coupling between mGluR and $\mathrm{Ca}$ channels.

\section{References}

Abe T, Sugihara $H$, Nawa $H$, Shigemoto R, Mizuno N, Nakanishi S (1992) Molecular characterization of a novel metabotropic glutamate receptor mGluR 5 coupled to inositol phosphate/ $\mathrm{Ca}^{2+}$ signal transduction. J Biol Chem 267:13361-13368.

Aramori I, Nakanishi S (1992) Signal transduction and pharmacological characteristics of a metabotropic glutamate receptor, mGluRl, in transfected CHO cells. Neuron 8:757-765.

Beech D, Bernheim L, Hille B (1992) Pertussis toxin and voltage dependence distinguish multiple pathways modulating calcium channels of rat sympathetic neurons. Neuron 8:97-106.

Bernheim L, Mathie A, Hille B (1992) Characterization of muscarinic receptor subtypes inhibiting $C a$ current and $M$ current in rat sympathetic neurons. Proc Natl Acad Sci USA 89:9544-9548.

Bessho Y, Nawa H, Nakanishi S (1993) Glutamate and quisqualate regulate expression of metabotropic glutamate receptor mRNA in cultured cerebellar granule cells. J Neurochem 60:253-259.

Bortolotto ZA, Collingridge GL (1992) Activation of glutamate metabotropic receptors induces long term potentiation. Eur J Pharmacol 214:297-298.

Bossu JL, Rodeau JL, Feltz A (1989) Decay kinetics of calcium currents in rat sensory neurones: analysis at two internal free calcium concentrations. Pfluegers Arch 414:89-91.

Bossu JL, Fagni L, Nooney J, Bockaert J, Feltz A (1993) Increased Ca channel activity due to metabotropic glutamate receptor stimulation in isolated rat cerebellar granule cells. J Physiol (Lond) 459: $250 \mathrm{P}$.

Bossu JL, De Waard M, Fagni L, Tansi F, Feltz A (1994) Characteristics of Ca channels responsible for voltage-activated $\mathrm{Ca}$ entry in rat cerebellar granule cells. Eur J Neurosci 6:335-344.

Brabet P, Dumuis A, Sebben M, Pantaloni C, Bockaert J, Homburger $\mathrm{V}$ (1988) Immunocytochemical localization of the guanine nucleotide-binding protein $\mathrm{G}_{0}$ in primary cultures of neuronal and glial cells. J Neurosci 8:701-708.

Chavis $\mathrm{P}$, Shinozaki H, Bockaert J, Fagni L (in press) The metabotropic glutamate receptor types $2 / 3$ inhibit L-type calcium channels via a pertussis toxin-sensitive $G$ protein in cultured cerebellar granule cells. J Neurosci, in press.

Chetkovich DM, Gray R, Johnston D, Sweatt JD (1991) $N$-methylD-aspartate receptor activation increases cAMP levels and voltagegated $\mathrm{Ca}^{2+}$ channel activity in area $\mathrm{CA} 1$ of hippocampus. Proc Natl Acad Sci USA 88:6767-6471.

Clapham DE (1993) A mysterious new influx factor? Nature 364:763764.
De Waard M, Feltz A, Bossu JL (1991) Properties of a high-threshold voltage-activated calcium current in rat cerebellar granule cells. Eur J Neurosci 3:771-777.

De Waard M, Seagar M, Feltz A, Couraud F (1992) Inositol phosphate regulation of voltage-dependent calcium channels in cerebellar granule neurons. Neuron 9:497-503.

Ellinor PT, Zhang JF, Randall AD, Zhou M, Schwarz TL, Tsien RW, Horne WA (1993) Functional expression of a rapidly inactivating neuronal calcium channel. Nature 363:455-458.

Fagni L, Bossu JL, Bockaert J (1991) Activation of a large conductance $\mathrm{Ca}^{2+}$-dependent $\mathrm{K}^{+}$channel by stimulation of glutamate phosphoinositide-coupled receptors in cultured cerebellar granule cells. Eur J Neurosci 3:778-789.

Fagni L, Chavis P, Bossu JL, Nooney J, Feltz A, Bockaert J (1993) Control of ionic channels by metabotropic glutamate receptors. J Neurochem 61:S198.

Feltz A, De Waard M, Bossu JL, Fagni L, Tanzi F, Feltz P (1990) Ca channels and dihydropyridine-sensitivity in rat cerebellar granule cells in culture. Soc Neurosci Abstr 16:955.

Forti L, Pietrobon D (1993) Functional diversity of L-type calcium channels in rat cerebellar neurons. Neuron 10:437-450.

Gray R, Johnston D (1987) Noradrenaline and $\beta$-adrenoceptor agonists increase activity of voltage-dependent calcium channels in hippocampal neurons. Nature 327:620-622

Guiramand J, Vignes M, Récasens M (1991) A specific transduction mechanism for the glutamate action on phosphoinositide metabolism via the quisqualate metabotropic receptor in rat brain synaptoneurosomes. II: Calcium dependency, cadmium inhibition. J Neurochem 57:1501-1509.

Hescheler J, Rosenthal W, Trautwein W, Schultz G (1987) The GTPbinding protein $G_{0}$ regulates neuronal calcium channels. Nature 325 : $445-447$.

Houamed KM, Kuijper JL, Gilbert TL, Haldeman BA, O'Hara PJ, Mulvihill ER, Almers W, Hagen FS (1991) Cloning, expression, and gene structure of a $G$ protein-coupled glutamate receptor from rat brain. Science 252:1318-1321.

Ito M, Karachot L (1990) Messengers mediating long-term desensitization in cerebellar Purkinje cells. Neuroreport 1:129-132.

Kalman D, O'Lague PH, Erxleben C, Armstrong DL (1988) Calciumdependent inactivation of the dihydropyridine-sensitive calcium channels in $\mathrm{GH}_{3}$ cells. J Gen Physiol 92:531-548.

Kleppisch T, Ahnert-Hilger G, Gollasch M, Spicher K, Hescheler J, Schultz G, Rosenthal W (1992) Inhibition of voltage-dependent Ca channels via $\alpha_{2}$-adrenergic and opioid receptors in cultured bovine adrenal chromaffin cells. Pfluegers Arch 421:131-137.

Lester RA, Jahr CE (1990) Quisqualate receptor-mediated depression of calcium currents in hippocampal neurons. Neuron 4:741-749.

Lledo PM, Homburger V, Bockaert J, Vincent JD (1992) Differential $G$ protein-mediated coupling of $\mathrm{D}_{2}$ dopamine receptors to $\mathrm{K}^{+}$and $\mathrm{Ca}^{2+}$ currents in rat anterior pituitary cells. Neuron 8:455-463.

Manzoni O, Fagni L, Pin JP, Rassendren F, Poulat F, Sladeczek F, Bockaert J (1990) (Trans)-1-amino-cyclopentyl-1,3-dicarboxylate stimulates quisqualate phosphoinositide-coupled receptors but not ionotropic glutamate receptors in striatal neurons and Xenopus oocytes. Mol Pharmacol 38:1-6.

Manzoni O, Prézeau L, Rassendren F, Sladeczek F, Curry K, Bockaert J (1993) Both enantiomers of 1-amino-cyclopentyl-1,3-dicarboxylate are agonists of metabotropic glutamate receptors coupled to phospholipase C. Mol Pharmacol 42:322-327.

Masu M, Tanabe Y, Tsuchida K, Shigemoto R, Nakanishi S (1991) Sequence and expression of a metabotropic glutamate receptor. Nature 349:760-765.

McGuinness N, Anwyl R, Rowan M (1991) Trans-ACPD enhances long-term potentiation in the hippocampus. Eur J Pharmacol 197: 231-232.

Mironov SL, Lux HD (1992) Glutamate selectively increases the highthreshold $\mathrm{Ca}^{2+}$ channel current in sensory and hippocampal neurons. Brain Res 580:341-344.

Nakanishi S (1992) Molecular diversity of glutamate receptors and implications for brain function. Science 258:597-603.

Nicoletti F, Wroblewski JT, Novelli A, Alho H, Guidotti A, Costa E (1986) The activation of inositol phospholipid metabolism as a signal-transducing system for excitatory amino acids in primary cultures of cerebellar granule cells. J Neurosci 6:1905-1911.

Prézeau L, Manzoni O, Homburger V, Sladeczek F, Curry K, Bockaert J (1992) Characterization of a metabotropic receptor: direct negative 
coupling to adenylyl cyclase and involvement of a pertussis toxinsensitive G protein. Proc Natl Acad Sci USA 89:8040-8044.

Sahara Y, Westbrook GL (1993) Modulation of calcium currents by a metabotropic glutamate receptor involves fast and slow kinetic components in cultured hippocampal neurons. J Neurosci 13:30413050.

Sayer RJ, Schwindt PC, Crill WE (1992) Metabotropic glutamate receptor-mediated suppression of L-type calcium current in acutely isolated neocortical neurons. J Neurophysiol 68:833-842.

Schocpp DD, Conn PJ (1993) Metabotropic glutamate receptors in brain function and pathology. Trends Pharmacol Sci 14:13-20.

Schoepp D, Bockaert J, Sladeczek F (1990) Pharmacological and functional characteristics of metabotropic excitatory amino acid receptors. Trends Pharmacol Sci 11:508-515.

Schultz G, Rosenthal W, Hescheler J, Trautwein W (1990) Role of G proteins in calcium channel modulation. Annu Rev Physiol 52:275292.

Sladeczek F, Pin J-P, Récasens M, Bockaert J, Weiss S (1985) Glutamate stimulates inositol phosphate formation in striatal neurones. Nature 317:717-719.

Sladeczek F, Récasens M, Bockaert J (1988) A new mechanism for glutamate receptor action: phosphoinositide hydrolysis. Trends Neurosci 11:545-549.

Slesinger PA, Lansman JB (1990) Calcium channel reopenings at resting membrane potentials following prior depolarization. Soc Neurosci Abstr 16:1174.
Slesinger PA, Lansman JB (1991) Inactivating and non-inactivating dihydropyridine-sensitive $\mathrm{Ca}$ channels in mouse cerebellar granule cells. J Physiol (Lond) 439:301-323.

Spanswick D, Pickering AE, Gibson IC, Logan SD (1992) Induction of rhythmic oscillations in rat sympathetic preganglionic neurons in vitro by a metabotropic-like excitatory amino acid receptor. J Physiol (Lond) 452:179P.

Sugiyama H, Ito I, Hirono C (1987) A new type of glutamate receptor linked to inositol phospholipid metabolism. Nature 325:531-533.

Swartz KJ, Bean BP (1992) Inhibition of calcium channels in rat CA3 pyramidal neurons by a metabotropic glutamate receptor. J Neurosci $12: 4358-4371$

Tanabe Y, Masu M, Ishii T, Shigemoto R, Nakanishi S (1992) A family of metabotropic glutamate receptors. Neuron 8:169-179.

Tsien RW, Ellinor PT, Horne WA (1991) Molecular diversity of voltage-dependent $\mathrm{Ca}^{2+}$ channels. Trends Pharmacol Sci 12:349-354.

Yue DT, Backx PH, Imredy JP (1990) Calcium-sensitive inactivation in the gating of single calcium channels. Science 250:1735-1738.

Zegarra-Moran O, Moran O (1993) Modulation of voltage-dependent calcium channels by glutamate in rat cerebellar granule cells in culture. Exp Brain Res 95:65-69.

Zheng F, Gallagher JP (1992) Burst firing of rat septal neurons induced by $1 S, 3 R$-ACPD requires influx of extracellular calcium. Eur J Pharmacol 211:281-282. 